\title{
An Attitude Approach to the Prediction of Entrepreneurship on Students at Institution of Higher Learning in Malaysia
}

\author{
Mohd Noor Mohd Shariff (Corresponding author) \\ College of Business, Universiti Utara Malaysia \\ 06010 Sintok, Kedah, Malaysia \\ E-mail: mdnoor@uum.edu.my \\ Mohammad Basir Saud \\ College of Business, Universiti Utara Malaysia \\ 06010 Sintok, Kedah, Malaysia \\ E-mail: basir372@uum.edu.my
}

\begin{abstract}
An attitude approach to the prediction of entrepreneurship has been the subject of extensive research in the developed world. However, this approach especially entrepreneurship attitude among students in the institutions of higher learning has not been conducted extensively in Malaysia and is ripe for research. This paper reports the findings on the entrepreneurship attitude perspective of the final year business management undergraduate students in one of the Institutions of Higher Learning in Malaysia. Fifty-eight undergraduates minored in entrepreneurship courses and sixty-five non-minored undergraduates from the Faculty of Business Management were tested and validated using the Entrepreneurial Attitude Orientation (EAO) scale instrument. Discriminant validity was used to test the known groups. There was a significance difference between known groups for two of the four EAO subscales (self-esteem and personal control); all subscales were entered into a stepwise discriminant function. The classification results showed that the overall number of cases classified correctly was 104 or 84.6 percent of the sample.
\end{abstract}

Keywords: Entrepreneurship, Undergraduates, Institution of Higher Learning, Entrepreneurial attitude orientation scale

\section{Introduction}

Previous research has shown a potential to create aspiring entrepreneurs in various fields such as academicians and fishermen (Louis, Blumenthal, Gluck \& Stoto, 1989; Roberts, 1991; Hatten \& Ruhland, 1995; Barcelona \& Valida, 1992; Mohd Noor, Ooi \& Mohd Zin, 2004; Mohd Noor \& Jamal, 2005). The studies conducted by these researchers were based on several perspectives, using the personality/character, demographics and attitudinal approaches.

The personality theories frequently loss its effectiveness in measuring entrepreneurial attitudes which according to Ajzen \& Fishbein (1977), the loss of its effectiveness in measuring entrepreneurial attitudes was due to the presence of increased margins of error related to all the situations that these instruments were used and not linking to the research concept. However, Robinson, Stimpson, Huefner \& Hunt (1991) stated that, the problems with the personality/traits approach when measuring entrepreneurship attitudes were regards to:

1) research methodologies that were not developed specifically to be used in measuring entrepreneurship;

2) different instruments that purport to measure the same concept actually correlate poorly;

3) personality theories are intended for use across a broad spectrum of situation, measuring general tendencies; and

4) the need for theoretical model that both influence and are influenced by activities in the environment that are interactive.

The demographic approach had also its own problems in measuring entrepreneurial attitudes because the approach was prone to generalizing individual groups within the population. Rychlak (1981) stated that future action was not influenced by demographic characteristics but more so by specific reactions to certain situations. In other words, entrepreneurial attitudes were determined by specific reaction to a situation and not by a set of common individual demographic characteristics. 
The structure of this article is as follows. The following section offers essential background information on the characteristics and entrepreneurial attitudes based on several perspectives propagated by previous literatures. The third section reviews the methodology employed that set out the hypotheses. The fourth and final section of the paper highlights the findings and discussions and conclusion respectively.

\section{Review of literature}

\subsection{Characteristics and entrepreneurial attitudes}

The attitude of individual to get involve in the field of entrepreneurship is driven by a number of factors that can be categorized as a Push Factors and Pull Factors. The Push Factors incorporate frustration that inherited entrepreneurial culture. Frustration result from limited opportunities, economic downturn and dissatisfaction. Pull Factors incorporate psychology and profit. Individuals will be pushed into entering business as a result of the frustration faced due to limited job opportunities and social mobility. Economic downturn also causes individuals to be influenced in becoming entrepreneurs because of the lack of job opportunities in both the public and private sectors.

Another reason is for individuals who do not have job satisfaction in his/her present jobs either because of the job itself, unsatisfactory remuneration, conflicting with leadership or organization culture. This is thought to be inappropriate which may lead to entrepreneurial attitudes. For some individuals who are already in the group with rich entrepreneurship culture, continual socialization process with the support and help in the form of material and moral will directly or indirectly encourage that individual to enter business.

Psychological encouragement also makes individuals to become influenced by entrepreneurship. The individual ego to carry out something that is self-created and being an own boss may also lead to entrepreneurial attitudes. Apart from this, the drive to make a profit is a strong motivator for aspiring entrepreneur. The profit derived from business is seen by many to be much more than being a mere wage earner.

Crant (1996) found that entrepreneurial attitudes could be linked to an individual consideration of owning a business. The research was conducted in a university in the United States and highlighted that gender; educational level and parents who own businesses contribute towards influencing entrepreneurial attitudes. Caird (1988a) stated that entrepreneurial attitudes could also be referred to individual levels of entrepreneurial attitudes to establish and run projects. Caird (1988b) also concluded that entrepreneurial attitudes tended to rely on the need for autonomy, internal locust of control, creativity, risk taking and self-believe.

A research analysis conducted by Mazzarol, Doss and Thein (1999) on the sampling of 93 respondents among entrepreneurs in Western Australia, found out that environmental factors (such as social factor, economics, politics and infrastructure development) and personality factors (such as individual character and the background of the respondents) influenced the drive to establish self-owned businesses

Entrepreneurial character and nature owned by some individuals together with demographic factors have also been proven to have close relationships towards the attitude to become an entrepreneur by establishing new businesses. Past research had shown that the interest of various demographic variables such as personality, human capital, ethnicity, marital status, educational level, family size, work status and experience, age, gender, socio-economics status, religion and nature of personality contribute towards establishing a business (Mazzarol, Doss \& Thein, 1999).

Entrepreneur characteristics inherent in someone may be linked with the attitude to establish a business as presented by researchers such as McClelland (1961) (need for achievement), Brockhous (1982) (attitude to take self internal control and risk), Schere (1982) (compromising with uncertainty), Greenberger and Sexton (1998) (need for personal control). However there are also background factors, which relate to individual personality such as previous employment (Ronstadts, 1985), family background (Matthews \& Moser, 1996), gender (Buttner \& Rosen, (1989), education (Storey, 1982) and ethnicity (Aldrich, 1980) which is also linked to the attitude to establish a business. Geographical factors and outside assistance also play a role in influencing the formation of new business by those who posses entrepreneurial characteristics (Chrisman, 1999).

Entrepreneurial attitudes can be associated with five main factors such as personal elements/traits factor (need for achievement, internal control, taking risk), personal environmental factor (family status, gender and having business-owning family), personal objective factor (being the owner of business, financial guarantee and vision), business environment factor (competition, societal attitudes towards new businesses and the accessibility of loan) and business idea factor (Naffziger, Hornby \& Kuratko, 1994). Research conducted by Mazzarol, Doss \& Thein (1999) found an attitude to set up an own business by a group of West Australian entrepreneurs based on demographic factors such as age, educational level, ethnicity, gender, previous work experience, jobless rate, residing location, family business experience and self-employment. Meanwhile, Crant (1996) studied on a group of first year undergraduates (91) and degree holders (90) found that entrepreneurship attitude among the respondents had significantly higher relationships with gender, education, family with business interest and a personal proactive attitude. 
In a comparative study conducted by Cromie and O’Donoghue (1992) on 194 managers and 661 first year degree undergraduate students with a group of entrepreneurs; they found that managers had high entrepreneurial attitudes by exhibiting characteristics and the nature for achievement, internal self control, need for autonomy, creativity, risk taking as well as higher self confidence as compared with the first year undergraduate students. Matthews and Moser (1996) study on 89 ex-business administration students, found that gender and families which own businesses, influenced entrepreneurial attitudes among the respondents. This finding supported the finding by Scherer and Brodzinski (1990), which found gender influenced the choice of entrepreneurship career among the respondents. The responsibility factor also influenced individuals when indulging in the field of entrepreneurship. This was proven by a research conducted by Buttner and Moore (1997) on 129 professional women and executives who have left their careers in major firms to become entrepreneurs by establishing their own companies. This course of action was taken to fulfil the movement factors (motivation) such as challenge, personal needs as well as balancing family and social responsibilities.

Other than the factors stated above, the factor of actually going through a relevant programme also influenced an individual to become an entrepreneur. This was further substantiated by the research conducted by Hatten and Ruhland (1995) on 220 college students who were following a programme sponsored by the Small Business Institute in USA. The research found that students which incline to become entrepreneurs was higher after competing the programme and it could be linked to high internal self control as well as age. Research conducted by Barcelona and Valida (1992) on 800 final year students at Universiti Utara Malaysia also found significant correlative existence between the respondents' personality and the characteristics of entrepreneurial attitudes. For technical entrepreneurs who have worked as university lecturers and researchers the elements such as family background, objective orientation, motivation and personality, work experience, education and age could be linked to the decision in becoming technical entrepreneurs (Roberts, 1991). Research by Louis et al. (1989) on lecturers at the Life Sciences Faculty at various universities in the United States also found that age and gender are factors that can influence lecturers into becoming academic entrepreneurs.

Researchers such as Ajzen (1982), Rosenberg and Hovland (1960) and Shaver (1987) defined attitude as the predisposition to respond in a generally favourable or unfavourable manner with respect to the object of the attitude. Allport (1935), Breckler (1983 and 1984), Carlson (1985), Kothandapani (1970) and others categorised attitude as the tripartite model consisting of three types of reaction to everything: affect, cognition, and conation. Robinson et al. (1991) defined:

The cognitive component consists of the beliefs and thought about an attitude object. The affective component consists of positive or negative feelings toward the object. The conative or behavioural component consists of behavioural intentions and predisposition to behave in a given way toward the object.

Robinson et al. (1991) concluded that the attitude theory has been used in many studies and benefited in terms of theoretical and practical approach on entrepreneurial attitudes. To substantiate the statement, Robinson et al. (1991) carried out a study to test the reliability of the "Entrepreneurial Attitude Orientation" (EAO) scale instrument on 63 undergraduate students while 54 entrepreneurs and 57 non-entrepreneurs were taken as a group to form discriminant validity for the EAO test. The result of the study indicated that the reliability of the EAO test was within the acceptable standard; entrepreneurs and non-entrepreneurs were significantly different for each of the four subscales and when submitted to discriminant analysis, three of the four subscales contributed significantly to the discriminant function. The findings of Robinson et al. (1991) has actually been supported by the study done earlier by Carlson (1985) which stated that the attitudes by individual to entrepreneurship can be measured by his/her attitude (consisting of the effective, cognitive and conative components) on the innovation, achievement, self-esteem, and personal control.

\section{Research hypotheses}

Based on findings of past researches and theoretical frameworks, the hypothesis presented in this analysis is:

$\mathrm{H}_{\mathrm{o}} 1$ : There is no significant difference between undergraduates minored in entrepreneurship and non-entrepreneur undergraduates in terms of the subscales (i.e. self-esteem, personal control, innovation and achievement).

\section{Methodology}

This research-design applied the method of cross sectional survey using questionnaires, which were distributed to the final year business management undergraduate students of Universiti Utara Malaysia. The questionnaires are divided into two (2) parts. Part A consisted of questions that relate to the respondent's background and his/her job experience and entrepreneurial courses or seminar that he/she has attended. While Part B consisted of 75 questions from the Entrepreneur Attitude Orientation (EAO) instrument, which include the main component of attitudes i.e. affective, cognitive, and conative and the sub-scales that are linked to the entrepreneurial attitudes which are the needs for achievement, self-esteem, personal control and innovation. A sample size of 274 respondents using the figure generated by Krejcie and Morgan (1970) was selected from the total population of 960 final year undergraduate business management students based on the stratified random sampling method. This is to ensure adequate representation of 
undergraduates minored in entrepreneurship and non-entrepreneur undergraduates. A total of 130 respondents returned their questionnaires but only $123(44.9 \%)$ of the questionnaires consisting of fifty-eight students minored in entrepreneurship and sixty-five non-minored students are usable. The sample size is excellent, because of the participants viewed this study as a valuable exercise. [Robinson et al. (1991) based their findings on 54 respondents (18\%) out of the 300 questionnaires that being sent].

\subsection{Reliability test result}

To determine the reliability of the responses given by the respondents, a reliability test was conducted to the dependent variable. The result of the test for the Cronbach's alpha value of 0.858 was obtained (Figure 1). This shows that the responses given by the respondents were highly reliable as the Reliability Coefficient is closer to 1 (one).

\subsection{Hypothesis testing}

MANOVA was run to test whether undergraduates minored in entrepreneurship had higher attitude subscale values than business undergraduates who are not minored in entrepreneurship. The predictive value of the four subscales was tested by running a stepwise discriminant analysis using Wilks' lambda to predict entrepreneur graduates and non-entrepreneur graduates based on the four subscales.

\section{Findings and discussions}

A MANOVA test showed a significant overall difference between entrepreneur undergraduates and non-entrepreneur undergraduates for self-esteem subscale in hypothesis $\mathrm{H}_{0} 3\left(\mathrm{~F}_{1},{ }_{121}=97.817, \mathrm{p}<0.05\right)$. The results of the univariate $\mathrm{F}$ tests along with the group means for each of the subscales are shown in Table 1. The findings supported those found by Robinson et al. (1991), where the univariate tests show a highly significance difference between entrepreneur and non-entrepreneur undergraduates for self-esteem and personal control, with the mean for the entrepreneur undergraduates group being higher than that of the non-enterpreneur undergraduates group in personal control.

The predictive value of the four subscales was tested by running a stepwise discriminant analysis using Wilks lambda to predict entrepreneurs and non-entrepreneurs based on the four subscales. One of the four subscales contributed significantly to the discriminant function. Table 2 provides a summary table and classification function coefficients. The subscales that did not contribute significantly to the discriminant function were achievement and innovation. The discriminant function had a lambda $=0.491\left(\chi^{2}=84.597, \mathrm{df}=4, \mathrm{p}<0.05\right)$.

Table 3 shows the classification results. There was $84.6 \%$ accuracy in predicting group membership (entrepreneur undergraduates and non-entrepreneur undergraduates) using the classification function coefficients. It seems likely that self-esteem and personal control were the greatest contributors to the discriminant function because of the operationalization of entrepreneur graduates used in this study (individuals who had to attends entrepreneur courses and having self-esteem to start a businesses). Further research may indicate a need to combine the subscales as the correlations were high enough for the subscales could be combined.

As shown in table 4, kappa is .692. A kappa of .692 indicates a highly moderate accuracy in prediction of the predicted group (non-entrepreneur undergraduates' vs entrepreneur undergraduates'). Kappa ranges in value from -1 to +1 . A value of 1 for kappa indicates perfect prediction, while a value of 0 indicates chance-level prediction (Green \& Salkin, 2005).

\section{Conclusion}

This study showed that the attitude approach to the study of entrepreneurship among the undergraduates minored in entrepreneurship and the non-minor entrepreneurship undergraduates showed a significant difference between them for the four subscales; and when submitted to discriminant analysis, two of the four subscales contributed significantly to the discriminant function. It seems likely that

Further testing using classification function coefficients indicated 84.6 percent accuracy in predicting group membership (entrepreneur undergraduates and non-entrepreneur undergraduates) and 0.692 indicated better than chance-level prediction of the predicted group membership.

\section{References}

Ajzen, I. (1982). On behaving in accordance with one's attitudes. In M.P. Zanna, E.T. Higgins, \& C.P. Herman, (Eds.), Consistency in social behavior: The Ontario symposium (2, pp. 3-15). Hillsdale, NJ: Erlbaum.

Ajzen, I., \& Fishbein, M. (1977). Attitude-behaviour relations: A theoretical analysis and review of empirical research. Psychological Bulletin, 84, 888 - 918.

Aldrich, H. (1980). Asian Shopkeepers as a Middleman Minority: A Study of Small Business. In E. A. Wandsworth, \& D. Eversley, (Eds). The Inner City: Employment and Industry. (pp. 389-407). London: Heinemann. 
Allport, G.W. (1935). Attitudes. In C. Murchison (Ed.), Handbook of Social Psychology, (pp. 798-884). Worchester, MA: Clark University.

Barcelona, A.C., \& Valida, A.C. (1992). Interrelationship between personal variables and entrepreneurial potentials of senior students of Universiti Utara Malaysia. Malaysian Management Review, 29(4), 15-28.

Breckler, S.J. (1983). Validation of affect, behavior and cognition as distinct components of attitude, Dissertation Abstracts International, 44(11B), pp. 3569 (Microfilm No. DA8403491).

Breckler, S.J. (1984). Empirical validation of affect, behavior and cognition as distinct components of attitude. Journal of Personality and Social Psychology, 47, 1191-1205.

Brockhous, R.H. (1982). The Psychology of Entrepreneur, Encyclopedia of entrepreneurship. New Jersey: Prentice Hall.

Buttner, E.H., \& Moore, D.P. (1997). Women's organizational exodus to entrepreneurship: Self-report motivations and correlated with success. Journal of Small Business Management, 35(1), 34 - 46.

Buttner, E.H., \& Rosen, B. (1989). Funding new business ventures: Are decision makers biased against women entrepreneurs? Journal of Business Venturing, 4, 249-261.

Caird, S. (1988a). Review of Methods Of Measuring Enterprise Attributes. Unpublished Paper, Durham University Business School

Caird, S. (1988b). Report On The Development And Validation Of A Measure Of General Enterprising Attitude, Unpublished Paper, Durham University Business School.

Carlson, S.D. (1985). Consistency of attitude components: A new proposal for an old problem, Dissertation Abstract International, 46(09B), 3261 (Microfilm No. AAC8526328).

Chrisman, J.J. (1999). The influence of outsider-Generated knowledge resource on venture creation. Journal of Small Business Management, 37(4), 42 - 58.

Crant, J.M. (1996). The proactive personality scale as a predictor of entrepreneurship intention. Journal of Small Business Management, 34(3), 42 - 49.

Cromie, S., \& O Donoghue, J. (1992). Assessing entrepreneurial attitudes. International Small Business Journal, 10(2), $66-70$.

Green, S.B., \& Salkind, N.J. (2005). Using SPSS for windows and macintosh: Analyzing and understanding data (4th ed.). New Jersey: Pearson Prentice Hall.

Greenberger, D.B., Sexton, D.L. (1998). An interactive model for new venture creation. Journal of Small Business Management, 26 (3), 107-18.

Hatten, T.S., \& Ruhland. S.K. (1995). Student attitude toward entrepreneurship as affected by participation in an SBI program. Journal of Education For Business, 70(4), 224 - 227.

Kothandapani, V. (1971). Validation of feeling, belief and intention to act as three components of attitude and their contribution to prediction of contraceptive behaviour. Journal of Personality and Social Psychology, 19, 321-333.

Krejcie, R.V., \& Morgan, D.W. (1970). Determining sample size for research activities. Educational and Psychological Measurement, 30, 607-610.

Lankard, B.A. (1991). The vocational education / entrepreneurship, ERIC Clearing House On Adult Career and Vocational Education, Digest No. 118

Louis, K.S., Blumenthal, D., Gluck, M.E., \& Stoto, M.A. (1989). Entrepreneur in academe: An exploration of behaviours among life scientist. Administrative Science Quarterly, 34(1), $110-113$.

Mathews, C.H., \& Moser, S.B. (1996). A longitudinal investigation of the impact of family background and gender on interest in small firm ownership. Journal of Small Business Management, 34(2), 29 - 43.

Mazzarol, T., Doss, N., \& Thein, V. (1999). Factors influencing small business start-up. International Journal of Entrepreneur Behaviour and Research, 5(2), 48 - 63.

McClelland, D.C. (1961). The Achieving Society. Princeton NJ: Van Nostrand.

Mohd Noor, M.S., \& Jamal, A. (2005). A study of entrepreneurship inclinations among the board members of the fisher's associations. International Journal of Management \& Entrepreneurship, 1(2), 82-95.

Mohd Noor, M.S., Ooi, Y.K., \& Mohd. Zin, M. (2004). Kecenderungan keusahawanan: Satu kajian empirikal di kalangan tenaga akademik Politeknik-Politeknik Malaysia. International Journal of Management Studies 11 (2), 171-194. 
Naffziger, D.W., Hornby, J.S., \& Kuratko D.F. (1994). A proposed research model of entrepreneurial motivation. Entrepreneurship Theory and Practice, 17(1), 49 - 55.

Roberts, E.B. (1991). Entrepreneur in high technology: Lessons from MIT and beyond. New York: Oxford University Press.

Robinson, P.B., Stimpson, D.V., Huefner, J.C., \& Hunt, H.K. (1991). An attitude approach to the prediction of entrepreneurship. Entrepreneurship Theory \& Practice, Summer, 15(4), 13 - 30.

Ronstadts, R.C. (1985). The educated entrepreneur: A new era of entrepreneurial education beginning. American Journal of Small Business, 10 (1), 7 - 23.

Rosenberg, M.J., \& Hovland, C.I. (1960). Cognitive, affective, and behavioural components of attitudes. In M.J. Rosenberg, C.I. Hovland, W.J. McGuire, R.P. Abelson, \& J.W. Brehm, (Eds.), Attitude organisation and change: An analysis of consistency among attitude components. New Haven, CT: Yale University.

Rychlak, J.F. (1981). Introduction to Personality and Psychotherapy: A Theory-Construction Approach (2nd Ed.). Boston: Houghton Mifflin.

Schere, J. (1982). Tolerance of ambiguity as a discriminating variable between entrepreneurs and managers. Proceedings of the Academy of Management, 42, 404-408.

Scherer, R.F. \& Brodzinski, J.D. (1990). Entrepreneur career selection and gender. A socialization approach. Journal of Small Business Management, 15(4)), 37 - 44.

Shaver, K.G. (1987). Principles of social psychology (3rd ed.). Cambridge, MA: Winthrop.

Storey, D.J. (1982). Entrepreneurship and the New Firm. Beckenham: Kent. 
Table 1. MANOVA analysis of entrepreneur undergraduates and non-entrepreneur undergraduates using the EAO Subscales

\begin{tabular}{|c|c|c|c|c|c|}
\hline \multirow{2}{*}{$\begin{array}{c}\text { Univariate Tests of } \\
\text { Significance }\end{array}$} & \multirow[t]{2}{*}{$\mathbf{F}$} & \multirow[t]{2}{*}{ df } & \multirow[t]{2}{*}{ Sig } & \multicolumn{2}{|c|}{ Group Means } \\
\hline & & & & $\begin{array}{c}\text { Entrepreneur } \\
\text { Undergraduates }\end{array}$ & $\begin{array}{c}\text { Non-entrepreneur } \\
\text { Undergraduates }\end{array}$ \\
\hline Achievement & 0.270 & 1,121 & .604 & 185.91 & 184.01 \\
\hline Self-Esteem & 97.817 & 1,121 & .000 & 33.06 & 54.58 \\
\hline Personal Control & 4.536 & 1,121 & .035 & 58.51 & 55.87 \\
\hline Innovation & 0.300 & 1,121 & .585 & 153.00 & 154.50 \\
\hline
\end{tabular}

$* \mathrm{p}<.05$

Table 2. Stepwise discriminant analysis

\begin{tabular}{|c|c|c|c|c|c|}
\hline \multirow[b]{2}{*}{ Subscale } & \multirow[b]{2}{*}{$\begin{array}{c}\text { F to } \\
\text { remove }\end{array}$} & \multirow[b]{2}{*}{$\begin{array}{c}\text { Wilks' } \\
\text { Lambda }\end{array}$} & \multirow[b]{2}{*}{ Sig } & \multicolumn{2}{|c|}{ Classification Function Coefficient } \\
\hline & & & & $\begin{array}{c}\text { Non-entrepreneur } \\
\text { Undergraduates }\end{array}$ & $\begin{array}{c}\text { Entrepreneur } \\
\text { Undergraduates }\end{array}$ \\
\hline Step 1: Self-Esteem & 97.82 & .553 & .000 & .536 & .373 \\
\hline Step 2: Personal Control & 4.54 & .964 & .035 & -.101 & .102 \\
\hline Step 3: Achievement & .270 & .998 & .604 & .211 & .184 \\
\hline Step 4: Innovation & .300 & .998 & .585 & .549 & .486 \\
\hline (Constant) & & & & -74.259 & -64.072 \\
\hline
\end{tabular}

$* \mathrm{p}<.05$

Table 3. Classification results from discriminant analysis

\begin{tabular}{cccc}
\hline Actual Group & No. of Cases & $\begin{array}{c}\text { Pon-Entrepreneur } \\
\text { undergraduates }\end{array}$ & $\begin{array}{c}\text { Entrepreneur } \\
\text { undergraduates }\end{array}$ \\
\hline Non-Entrepreneur Graduate & 58 & $52(89.7 \%)$ & $6(10.3 \%)$ \\
\hline Entrepreneur Graduate & 65 & $13(20.0 \%)$ & $52(80.0 \%)$ \\
\hline
\end{tabular}

Percent of cases correctly classified: $84.6 \%$

Table 4. Results of kappa analysis

\begin{tabular}{cccccc}
\hline & & Value & $\begin{array}{c}\text { Asymp. } \\
\text { Std. Error }\end{array}$ & Approx. T & Approx. Sig \\
Measure of Agreement & Kappa & .692 & 0.065 & 7.725 & .000 \\
N of Valid Cases & 123 & & & \\
\hline
\end{tabular}

\begin{tabular}{|l|}
\hline Reliability Coefficients \\
$\mathrm{N}$ of Cases $=123$
\end{tabular}

Figure 1. Test result of the reliability analysis of the responses

Source: Adopted from Robinson et al. (1991), Table 1, and p. 22. 